\title{
The Effect of Short Irrigation Frequencies on the Development of Verticillium Wilt in the Susceptible Olive Cultivar 'Picual' under Field Conditions
}

\author{
M. Pérez-Rodríguez, Departamento de Agronomía, Universidad de Córdoba, Campus Universitario de Rabanales, Edificio Celestino \\ Mutis (C4), 14071, Córdoba, Spain; N. Serrano and O. Arquero, IFAPA, Centro 'Alameda del Obispo', 14080 Córdoba, Spain; \\ F. Orgaz, Instituto de Agricultura Sostenible, Consejo Superior de Investigaciones Científicas (CSIC), Apartado 4084, 14080, Córdoba, \\ Spain; and J. Moral and F. J. López-Escudero, Departamento de Agronomía, Universidad de Córdoba, Campus Universitario de \\ Rabanales
}

\begin{abstract}
Pérez-Rodríguez, M., Serrano, N., Arquero, O., Orgaz, F., Moral, J., and López-Escudero, F. J. 2016. The effect of short irrigation frequencies on the development of Verticillium wilt in the susceptible olive cultivar 'Picual' under field conditions Plant Dis. 100:1880-1888.

The effect of irrigation frequency (daily [T1], biweekly [T2], and dryland [T3]) on Verticillium wilt of olive was studied in two fields that were naturally infested with Verticillium dahliae in southern Spain and planted to 'Picual' olive. Disease onset (average 61 weeks after planting) and disease incidence (average $75.6 \%$ ) did not differ among irrigation treatments in both fields. Irrigation consistently increased disease development regarding dryland treatment, but this effect varied over time. In experiment I, T1, the relative area under the disease progress curve was greater on all recording dates (ranging from 15.8 to 33.7) in comparison with T3 (average 6.6). Data for experiment II were similar to this on the most favorable dates for disease

(March to April). The T2 treatment value varied over time depending on the season and experimental field, being difficult to differentiate from the values of T1 and T3. Significant correlation between disease incidence and severity increments during spring and fall with the soil water content of the same or previous favorable seasons was observed. Through these correlations, we detected soil water contents of $24.3 \%$ (experiment I) and $23.6 \%$ (experiment II), where the increments of disease parameters remained at zero. Therefore, scheduling irrigation treatments based on rainfall may be a feasible method for maintaining the soil moisture below levels that favor for disease development.
\end{abstract}

The Spanish Research Group AGR-216 from the University of Cordoba has conducted experiments over the last 4 years to study the effect of irrigation on the onset and development of Verticillium wilt of olive (VWO), which is caused by Verticillium dahliae. Verticillium wilt is the most important disease of this tree crop in all areas where it is cultivated, and particularly in Andalucía (southern Spain) (Jiménez-Díaz et al. 2012; López-Escudero and Mercado-Blanco 2011; (Lahkim) Tsror 2011). There are several reports that excessive irrigation or soil moisture increased Verticillium wilt development in herbaceous hosts such as potato (Cappaert et al. 1992), cauliflower (Xiao and Subbarao 2000), eggplant (Bletsos et al. 1999), and cotton (Wheeler et al. 2012). Limiting the amount of water applied to the field may reduce severity of the disease in some plant species such as potato (Cappaert et al. 1992). Berlanger and Powelson (2000) reported that overwatering, particularly early in the growing season, resulted in increased infection and, thus, increased disease severity. Data on the effect of excess water on woody hosts of $V$. dahliae is scarce (Hiemstra and Harris 1998) but increased disease has been reported in some hosts; namely, cacao (Emechebe 1980), apricot (Vigouroux 1984), and maple (Shufelt and Linderman 1986).

Preliminary studies on the effect of excess soil moisture on VWO were conducted in semicontrolled conditions (i.e., in microplots filled with naturally infested soil), in which plants were watered daily, weekly, biweekly, or with deficit irrigation (Pérez-Rodríguez et al. 2015). In the same experiment, the interaction of irrigation treatments with olive cultivars with different levels of resistance to V. dahliae ('Picual', susceptible; 'Arbequina', moderately susceptible; and 'Frantoio', resistant) was also assessed. Daily irrigation resulted in

Corresponding author: M. Pérez-Rodríguez;

E-mail: marioagro25@hotmail.com

Accepted for publication 1 May 2016.

http://dx.doi.org/10.1094/PDIS-09-15-1018-RE

(C) 2016 The American Phytopathological Society greater VWO development in Picual compared with the other combinations of cultivar and irrigation frequency tested.

However, there is little information regarding the effect of irrigation frequencies on VWO disease progress in field conditions. This is difficult to study because the progress of Verticillium wilt in olive is modified by environmental changes, particularly by seasonal variations in rainfall and temperature over time, but also by such factors as differences in the inoculum density (ID) of the pathogen and its virulence, types of soil, and cultural management. Nevertheless, we conducted long-term experiments at two locations in Spain to examine whether short irrigation frequencies, which elevate the level of water content in soil to its upper limit, increase the risk of VWO in fields in which $V$. dahliae is present in the soil.

\section{Materials and Methods}

Field experimental plots.

Experiment I. Soil properties and $\mathrm{V}$. dahliae $I D$. The experiment was conducted in naturally infested soil in the municipality of Andújar (Jaen province, upper Guadalquivir Valley; X: 409.007,90763; Y: 4.204.618,5853, according to system ED50/UTM zone 30N) in southern Spain from June 2013 to April 2015. The soil of the plot was clay soil $\left(\mathrm{pH}\right.$ in $\mathrm{ClK}=7.47$, organic matter $=1.27 \%$, total $\mathrm{CaCO}_{3}$ equivalent $=31.60 \%$, active $\mathrm{CaCO}_{3}=14.24 \%$, available $\mathrm{K}=570$ ppm, available $P=11.5 \mathrm{ppm}$, and organic $n=0.06 \%$ ).

The hydraulic properties of the soil were assessed using a 12-liter plastic pot filled with the soil, which was watered to saturation and covered with a black plastic film to avoid evaporation. The pot was allowed to drain freely and, thereafter, it was weighed and dried in an oven at $70^{\circ} \mathrm{C}$ for 7 days. Then, the pot was again weighed to determine the mass of water and the mass of solid soil. The upper limit of soil water content $\left(\theta_{\mathrm{UL}}\right)$ was determined according to the gravimetric method using the following formula: $\theta_{\mathrm{UL}}=\left(V_{\mathrm{w}}\right) /\left(V_{\mathrm{s}}\right)$, where $V_{\mathrm{w}}=$ the mass of water and $V_{\mathrm{s}}=$ the total volume of soil. The $\theta_{\mathrm{UL}}$ value was $0.32 \mathrm{~m}^{3} \mathrm{~m}^{-3}$.

To determine the available water in this soil, the lower limit of the soil water content $\left(\theta_{\mathrm{LL}}\right)$ was measured using barley seed that were sown in a 12-liter plastic pot filled with soil. Irrigation was cut when the plants reached maximum vegetative growth and, after plants had 
died, the soil water content was determined using the above formula. The $\theta_{\mathrm{LL}}$ value was $0.18 \mathrm{~m}^{3} \mathrm{~m}^{-3}$.

The plot had been cultivated with cotton for the five previous years, and it was surrounded by olive orchards severely affected by VWO. The initial ID of $V$. dahliae of the plot soil was determined as described by Trapero et al. (2013). Forty 100-g soil subsamples were homogeneously taken from the plot from a depth of 25 to $30 \mathrm{~cm}$ using a cylindrical auger. Subsamples were mixed, bulked, and crumbled. Resulting soil sample was then air dried under ambient conditions for 3 weeks. The sample was then passed through a $0.8-\mathrm{mm}$ sieve to remove organic debris and large particles, mixed by hand, and air dried for an additional week. The $V$. dahliae ID was estimated by the wet sieving technique (Huisman and Ashworth 1974). The sample ( $25 \mathrm{~g}$ ) was suspended in $100 \mathrm{ml}$ of distilled water, shaken at $270 \mathrm{rpm}$ for $1 \mathrm{~h}$, and filtered through 150- and $35-\mu \mathrm{m}$ sieves. The residue retained on the $35-\mu \mathrm{m}$ sieve was recovered in $100 \mathrm{ml}$ of distilled water. Finally, $1 \mathrm{ml}$ of the suspension was plated onto plates (20 replications) of a modified sodium polypectate agar medium plate (Butterfield and DeVay 1977). After 14 days of incubation at 22 to $24^{\circ} \mathrm{C}$ in the dark, soil residues were removed with tap water, and colonies of $V$. dahliae were counted under a stereoscope. The ID was estimated by the number of colonies of $V$. dahliae and expressed as propagules or microsclerotia per gram (MS/g) of airdried soil. For this soil, ID reached 5.4 MS/g of soil. At the end of the experiment, the ID of the pathogen in soil was assessed for all irrigation treatments and quantified using the method described above.

The isolation and molecular characterization of the pathogen in the soil were conducted using the methodology described by LópezEscudero and Blanco-López (2005b) and Mercado-Blanco et al. (2003). This analysis revealed that $82.7 \%$ of the soil isolates of the pathogen recovered from the soil were highly virulent strains (defoliating pathotype).

Plant material. For planting, 20-month-old rooted olive cuttings of susceptible Picual (López-Escudero et al. 2004; Trapero et al. 2013) were used. The cuttings were collected from $V$. dahliae-free mother olive plants from the World Olive Germplasm Bank (Caballero and Del Río 2008) from the Instituto de Investigación y Formación Agraria y Pesquera, Research Center 'Alameda del Obispo', Córdoba, Spain, and propagated according to Caballero and Del Río (2010). At planting time, the plants were 1.3 to $1.5 \mathrm{~m}$ high, with a single trunk and three or four secondary branches.

Orchard establishment, experimental design, and irrigation treatments. The experimental olive orchard was established in June 2013. The plot occupied 0.2 ha ( 28 by $67.5 \mathrm{~m})$, with an average slope of $4 \%$. The orchard consisted of five rows (distance between rows $=$ $7 \mathrm{~m}$ and between plants $=2.5 \mathrm{~m}$ ). For soil management, reduced tillage and herbicide applications were used.

A randomized block design with five blocks was used. There were 27 plants per block (row), three irrigation treatments per block, and 9 plants per treatment. Three irrigation frequencies were assessed: daily (T1), biweekly (T2), and dryland (T3). The plants were drip irrigated using a programmable irrigation controller (Image 6 Rain Bird; Rain Bird Iberica S.A.) connected to two PVC water pipes (50 $\mathrm{mm}$ in diameter and $40 \mathrm{~m}$ long) extended in a direction perpendicular to the tree rows. From these pipes, two 16-mm pipes started per row (one each for the T1 and T2 treatments), with 2 and 12 compensating drippers ( 8 liters/h; Netafim) per tree for the T1 and T2 irrigation treatments, respectively.

The soil water content in each treatment was recorded every 15 days just before irrigation using a time domain reflectometry system (6050X1 Trase System I; Soil Moisture Equipment Corp.). Subsequently, in treatments $\mathrm{T} 1$ and $\mathrm{T} 2$, at every irrigation date (daily or every 15 days, respectively), the soil was irrigated until it reached the upper limit of water content.

Experiment II. Inoculating the experimental site and collecting and characterizing a naturally infested soil. Experiment II was conducted in a previously $V$. dahliae-free site located in the Campus of Rabanales of the University of Córdoba (Córdoba province, middle Guadalquivir Valley; X: 349349.734175 m; Y: 4197887.92704 m, according to system ED50/UTM zone $30 \mathrm{~N}$ ) in southern Spain, from
December 2013 to May 2015. The selected site occupied 0.06 ha (19 by $30 \mathrm{~m}$ ), had an average slope of $1.8 \%$, and was previously tilled by a tractor to remove weeds. One hundred tons of soil naturally infested by the pathogen was collected from a field located in the municipality of Utrera (Sevilla, southern Spain) in a marsh area annually cropped with $V$. dahliae hosts, primarily tomato, cotton, and eggplant. The soil in this zone is heavily infested with highly virulent strains of $V$. dahliae (cotton-defoliating pathotype), and VWO incidence and mortality has been reported to develop quickly (Trapero et al. 2013). Indeed, soil from this zone was successfully used in previous studies to determine the effect of irrigation frequencies on VWO development in microplots (Pérez-Rodríguez et al. 2015). The ID of the collected soil, assessed as described above, was $1.2 \mathrm{MS} / \mathrm{g}$ of soil, and almost $100 \%$ of soil isolates of the pathogen recovered from it were characterized as highly virulent strains (defoliating pathotype). As in experiment I, the final value of ID was assessed for all irrigation treatments.

The soil was a clay soil $(\mathrm{pH}$ in $\mathrm{ClK}=7.45$, organic matter $=1.57 \%$, total $\mathrm{CaCO}_{3}$ equivalent $=25.64 \%$, active $\mathrm{CaCO}_{3}=3.33 \%$, available $\mathrm{K}=475 \mathrm{ppm}$, available $P=8.4 \mathrm{ppm}$, and organic $n=0.07 \%$ ). The hydraulic properties of the soil were assessed as described above. Thus, $\theta_{\mathrm{UL}}$ and $\theta_{\mathrm{LL}}$ values of the soil in experiment II were 0.37 and $0.17 \mathrm{~m}^{3} \mathrm{~m}^{-3}$, respectively.

Plot infestation, orchard establishment, experimental design, and irrigation treatments. In October 2011, the collected soil was transported by trucks to the Campus of Rabanales and was homogenized by continuous crumbling and mixing using a tractor shovel at the experiment site. In the plot, trenches $(30 \mathrm{~m}$ long, $1 \mathrm{~m}$ wide, and $70 \mathrm{~cm}$ deep) were dug and subsequently filled with the infested soil (bulk density $=1,300 \mathrm{~kg} / \mathrm{m}^{3}$ ). During the filling, plastic sheets $2 \mathrm{~mm}$ thick were used to line the trenches of soil and, thus, separate the different irrigation treatments (see below) and prevent water from passing from one to another. The filled trenches were finally covered with a 10-cm layer of the original soil of the plot to prevent infested soil dispersal.

Picual plants that were of the same age as those in experiment I and propagated with the same procedure were used for planting. The olive plantation was established in December 2013. The orchard consisted of four rows (distance between rows $=5 \mathrm{~m}$ and between plants $=2 \mathrm{~m}$ ). The plot occupied 0.06 ha $(20$ by $30 \mathrm{~m})$, with an average slope of $1.8 \%$. For soil management, reduced tillage and herbicide applications were used. As in experiment I, T1, T2, and T3 treatments were studied, and the plants were arranged according to a randomized block design with four blocks. There were 15 plants per block (row), three irrigation treatments per block, and 5 plants per treatment. The irrigation system was installed and controlled as described for experiment I. The soil water content in each treatment was recorded as in experiment I, and the irrigation program was decided according to the same criteria.

Assessment of disease progression. Experiments I and II were inspected every 2 weeks for 23 and 18 months after planting, respectively, for disease symptoms. Disease severity was estimated based on a 0 -to-4 rating scale according to the percentage of plant tissue affected by any of the following symptoms: chlorosis, necrosis, or defoliation, where $0=$ no symptoms; $1=1$ to $33,2=34$ to 66 , and $3=67$ to $99 \%$ affected tissue; and $4=$ dead plant. These values were used to construct the progress curves for disease incidence (DI) and mean disease severity of the affected plants over time during the recording period. For both experiments, the curves of mean severity over time were adjusted to the logistic model (Pérez-Rodríguez et al. 2015) $y_{\mathrm{L}}(t)=\rho_{1} /\left\{1+\exp \left[-\left(\rho_{2}+\rho_{3} t\right)\right]\right\}$.

Moreover, the time that elapsed from the plantation establishment to the point where $50 \%$ of trees were diseased $\left(\mathrm{DI}_{50}\right)$ was also calculated for each treatment.

At the end of the experiment, the relative area under the disease progress curve (RAUDPC) was estimated as the percentage with regard to the maximum potential value for the period between the first symptom appearance and the end of the experiment using the formula of Campbell and Madden (1990): RAUDPC $=\{[t / 2 \times$ $(\mathrm{S} 2+2 \times \mathrm{S} 3+\ldots+2 \mathrm{Si}-1+\mathrm{Si})] / 4 \times n\} \times 100$, where $t=$ the interval in days between observations, $\mathrm{Si}=$ the final mean severity, $4=$ the 
maximum disease rating, and $n=$ the number of observations. The final percentage of dead plants, or mortality, was also considered in estimating the severity of the reactions. The time that elapsed from the transplanting to the onset of disease symptoms (FS) was determined for all irrigation treatments.

Plant infection was confirmed by isolating the fungus from the affected shoots or leaf petioles of diseased plants via microbiological methods, as described by López-Escudero and Blanco-López (2001). Briefly, affected twigs showing disease symptoms mentioned above were collected from wilted plants (three 20 -cm-long twigs per tree). When leaf petioles were used, 10 defoliated leaves per tree were collected just after affected shoots in the tree were shaken. For pathogen isolation, pieces of collected twigs were washed in running tap water, bark was removed, and woody tissues were surface disinfested in $0.5 \%$ sodium hypoclorite for $1 \mathrm{~min}$. Chips of wood were placed onto potato dextrose agar (PDA) or acidified PDA. Plates were incubated at $24^{\circ} \mathrm{C}$ in the dark for 5 to 6 days. Leaf petioles cut from defoliated leaves were processed in a similar way. Almost all affected samples were also analyzed using polymerase chain reaction methods according to the methodology of MercadoBlanco et al. (2003), with the aim to determine the pathotype of the isolates recovered from trees.

Relationship between increase in disease parameters (incidence and severity) and soil water content in experiments I and II. Soil water content data and disease parameters (incidence and severity) were grouped by seasons: spring (1 April to 1 June), summer (15 June to 15 September), fall (1 October to 15 December) and winter (1 January to $15 \mathrm{March}$ ). The effect of increase in disease parameters per day of each irrigation treatment was calculated as (last day of season) - (first day of the next season -1). The soil water content in each of three treatments was computed as average values of all days of the season.

A nonlinear asymptotic regression model was used to evaluate the relationship between soil water content in percentage and increase in diseased parameters (incidence and severity): $Y=a-b \times c^{\mathrm{x}}$. This equation has three parameters: $a$ is the horizontal asymptote on the righthand side when $0<c<1, a-b$ is the response when $x=0$, and $c$ is the growth rate of the curve.

The minimum soil water content (MSWC; the soil water content in percentage for which DI and severity were zero) of these curves was calculated.

Rainfall data. Rainfall data were collected from the two official weather stations of The Junta de Andalucía nearest to the experimental sites (Anonymous 2015). Then, the agroclimatic stations located in Finca La Paz (La Higuera de Arjona, Jaen province; UTM coordinates X: $411463.0 \mathrm{~m}$ and $\mathrm{Y}: 4200610.0 \mathrm{~m}$, altitude $=267.0 \mathrm{~m}$, latitude $37^{\circ} 56^{\prime} 55^{\prime \prime} \mathrm{N}$, and longitude $04^{\circ} 00^{\prime} 27^{\prime \prime} \mathrm{W}$ ) and Finca Alameda del Obispo (Córdoba, Córdoba province; UTM coordinates $\mathrm{X}$ : $341399.0 \mathrm{~m}$ and $\mathrm{Y}: 4191480.0 \mathrm{~m}$, altitude $117.0 \mathrm{~m}$, latitude $37^{\circ} 51^{\prime} 25^{\prime \prime} \mathrm{N}$, and longitude $04^{\circ} 48^{\prime} 10^{\prime \prime} \mathrm{W}$ ) were used for the field trials at Andújar (experiment I) and the University of Córdoba (experiment II), respectively.

Data analysis. For each trial, individual analyses of variance of the evaluated parameters were performed using Statistix 10.0 (Analytical Software). The data were analyzed in a randomized completed block design, with studied diseased parameters as the dependent variable. The mean values of analyzed parameters were compared using Fisher's protected least significant difference test at $P=0.05$. The FS parameter was analyzed using Kaplan-Meier survival analysis (Kaplan and Meier 1958), in which the survival times were calculated as the week in which disease symptoms appeared for the first time. Comparisons were tested using the log-rank test at $P=0.05$.

The relationship between the increase in incidence, severity, and the soil water content of the three treatments during each season was studied using the Pearson correlation, and then by a nonlinear asymptotic regression model described above. The Akaike's information criterion and pseudo- $R^{2}$ parameter were used to evaluate the appropriateness of the logistic model and the asymptotic regression model to describe data. The effect of water content during seasons on the increase of incidence or severity during a given season was also studied by multiple linear regression analysis. We evaluated the appropriateness of multiple linear regression according to the significance of the estimated individual parameters and general significance of model $(P \leq 0.05)$, Mallow's $C p$ statistic, Akaike's information criterion, the coefficient of determination $\left(R^{2}\right), R^{2}$ adjusted for degrees of freedom $\left(R_{a}^{2}\right)$, and the pattern of residuals over predicted and independent variables. The collinearity among parameters was checked according to the variance inflaction factor.

\section{Results}

ID of Verticillium dahliae in the soil. Soil analyses showed that the pathogen remained viable in the soil in both trials throughout the investigation period. The $V$. dahliae population detected in soil reached $5.4 \pm 1.06$ and $1.2 \pm 0.4 \mathrm{MS} / \mathrm{g}$ in experiments I and II, respectively. No significant differences $(P>0.05)$ were detected in the initial and final amounts of infective propagules between different irrigation treatments.

Disease symptoms and pathogen isolation from affected tissues. Typical symptoms of the disease (López-Escudero and Blanco-López 2001; Trapero et al. 2013) (i.e., wilting, dieback, or defoliation) were usually observed in the affected plants. Wilting primarily started at the lower branches and developed as a generalized green leaf defoliation that affected the entire tree canopy. However, partial defoliations of green leaves affecting the higher branches were observed occasionally. Desiccation of flowers occurred during spring and early summer. Occasionally, primarily in early spring, affected plants exhibited wilt, chlorosis, and rolling of leaves without the defoliation of green leaves. These plants became completely wilted, and necrotic leaves remained attached to shoots. Affected plants were consistently colonized by the pathogen and a collection of $57 \mathrm{~V}$. dahliae isolates was obtained from both fields ( 23 from experiment I and 34 from experiment II). Of the recovered isolates, $89 \%$ (19 from experiment I and 32 from experiment II) belonged to the defoliating pathotype.

Disease progression. Verticillium wilt symptoms were first observed at 48 and 42 weeks in experiments I and II, respectively (Table 1). Time to the onset of the disease symptoms from orchard establishment did not differ between irrigation treatments, and was very similar in the two experiments. (62.2 and 60.7 weeks for experiments I and II, respectively).

In experiment I, the DI increased faster in trees under $\mathrm{T} 1$ irrigation treatment compared with those in $\mathrm{T} 2$ and $\mathrm{T} 3$ irrigation treatments (Fig. 1). For example, in mid-May 2014, DI was $33 \%$ in the T1 treatment and 17 and $2 \%$ in the $\mathrm{T} 2$ and $\mathrm{T} 3$ treatments, respectively. Throughout June 2014, there was little increase in the number of new diseased trees; however, starting in July, DI increased gradually and, by October, DI was 89,64 , and $54 \%$ for T1, T2, and T3, respectively (Fig. 1). No significant differences between treatments were found $(P=0.143)$ in the final DI values, which were 91.3, 76.6, and $63.6 \%$ for $\mathrm{T} 1, \mathrm{~T} 2$, and $\mathrm{T} 3$, respectively (Table 1; Fig. 1).

In experiment II, the progress of the DI was similar for the T1 and T2 treatments. The first plants were symptomatic in early October 2014 and, thereafter, the percentage of affected plants progressively increased until the end of the observations in spring 2015, reaching final values of 83.7 and $78.7 \%$ of plants in the T1 and T2 treatments, respectively. DI increments were primarily recorded from September to December 2014 and in spring 2015. Although the final values of DI registered for T3 were not significantly different $(P=0.355)$ from those of T1 and T2 (Table 1), the disease was considerably delayed in T3, and plants did not exhibit disease symptoms until April 2015 (Fig. 1). Nevertheless, despite this delay in disease onset, $60 \%$ of the plants under the T3 treatment developed some of the symptoms described above during spring 2015 (Fig. 1).

After 23 months of observations in experiment I, the percentage of trees killed by the pathogen in irrigated treatment $\mathrm{T} 1$ was significantly greater than that of T3 $(28.4$ and $6.4 \%$, respectively; $P=$ 0.04). In experiment II, 18 months after planting, there were no differences in plant mortality (Table 1 ).

The $\mathrm{DI}_{50}$ for T1 treatment was 58 and 55 weeks in experiments I and II, respectively (Table 2). For the other two treatments, the $\mathrm{DI}_{50}$ was greater than 61 weeks.

Differences were detected in the RAUDPC among treatments, although the trends were the same across all months. The RAUDPC of 
trees in $\mathrm{T} 1$ was always greater than that of trees in $\mathrm{T} 2$, and was lowest for trees in T3. In experiment I, the RAUDPC for trees in the T1 treatment in June 2014 (15.8) was significantly higher than for trees that received T2 and T3 treatments (7.9 and 2.1, respectively; Table 2). In
August and October, the RAUDPC of the trees in the T3 treatment (4.8 and 6.9, respectively) was significantly less than the RAUDPC of trees in T1 and T2; only in June 2014 did the RAUDPC of T2 differ significantly from T1 (Table 2). In experiment II, significant

Table 1. Effect of irrigation frequency on the final estimated disease values in two experimental orchards of susceptible Picual olive established on naturally infested soils by Verticillium dahliae ${ }^{\mathrm{u}}$

\begin{tabular}{|c|c|c|c|c|c|c|}
\hline \multirow[b]{2}{*}{ Experiment, treatment } & \multicolumn{2}{|c|}{ FS $\left(\right.$ weeks) ${ }^{\mathrm{v}}$} & \multirow[b]{2}{*}{ Mortality $(\%)^{\mathrm{w}}$} & \multirow[b]{2}{*}{$\operatorname{MnSev}^{x}$} & \multirow[b]{2}{*}{ DI $(\%)^{y}$} & \multirow[b]{2}{*}{ Affected $^{\mathbf{z}}$} \\
\hline & $\overline{\text { Range }}$ & $\overline{\text { Mean }}$ & & & & \\
\hline \multicolumn{7}{|l|}{ Experiment I } \\
\hline T1 (daily irrigation) & $48-83$ & $57.1 \mathrm{a}$ & $28.4 \mathrm{a}$ & $1.8 \mathrm{a}$ & $91.3 \mathrm{a}$ & $2.1 \mathrm{a}$ \\
\hline $\mathrm{T} 2$ (biweekly irrigation) & $48-99$ & $64.0 \mathrm{a}$ & $17.3 \mathrm{ab}$ & $1.4 \mathrm{ab}$ & $76.6 \mathrm{a}$ & $1.7 \mathrm{a}$ \\
\hline T3 (dryland-rainfed) & $48-99$ & $65.4 \mathrm{a}$ & $6.4 \mathrm{~b}$ & $0.8 \mathrm{~b}$ & $63.6 \mathrm{a}$ & $1.4 \mathrm{a}$ \\
\hline Mean & $\ldots$ & 62.2 & 17.3 & 1.3 & 77.2 & 1.7 \\
\hline \multicolumn{7}{|l|}{ Experiment II } \\
\hline T1 (daily irrigation) & $42-70$ & $55.8 \mathrm{a}$ & $20.0 \mathrm{a}$ & $1.2 \mathrm{a}$ & $83.7 \mathrm{a}$ & $1.5 \mathrm{a}$ \\
\hline T2 (biweekly irrigation) & $42-70$ & $58.5 \mathrm{a}$ & $27.5 \mathrm{a}$ & $2.0 \mathrm{a}$ & $78.7 \mathrm{a}$ & $2.5 \mathrm{a}$ \\
\hline T3 (dryland-rainfed) & $66-70$ & $67.8 \mathrm{a}$ & $15.0 \mathrm{a}$ & $1.3 \mathrm{a}$ & $60.0 \mathrm{a}$ & $1.9 \mathrm{a}$ \\
\hline Mean & $\ldots$ & 60.7 & 20.8 & 1.5 & 74.1 & 1.9 \\
\hline
\end{tabular}

u Trees were surveyed every 2 weeks for symptom development over 23 months (June 2013 to April 2015) in experiment I and 18 months (December 2013 to

May 2015) in experiment II. Values listed in columns followed by the same letter were not significantly different at $P=0.05$.

$\checkmark \mathrm{FS}=$ time from orchard establishment to the onset of disease symptoms. Differences were estimated according to the log rank test.

${ }^{\mathrm{w}}$ Mortality $(\%)=$ differences were estimated according to Fisher's protected least significant difference (LSD) test.

${ }^{\mathrm{x}} \mathrm{MnSev}=$ mean severity. Differences were estimated according to Fisher's protected LSD test.

y Disease incidence.

z Affected = MnSev of symptomatic plants. Differences were estimated according to Fisher's protected LSD test.
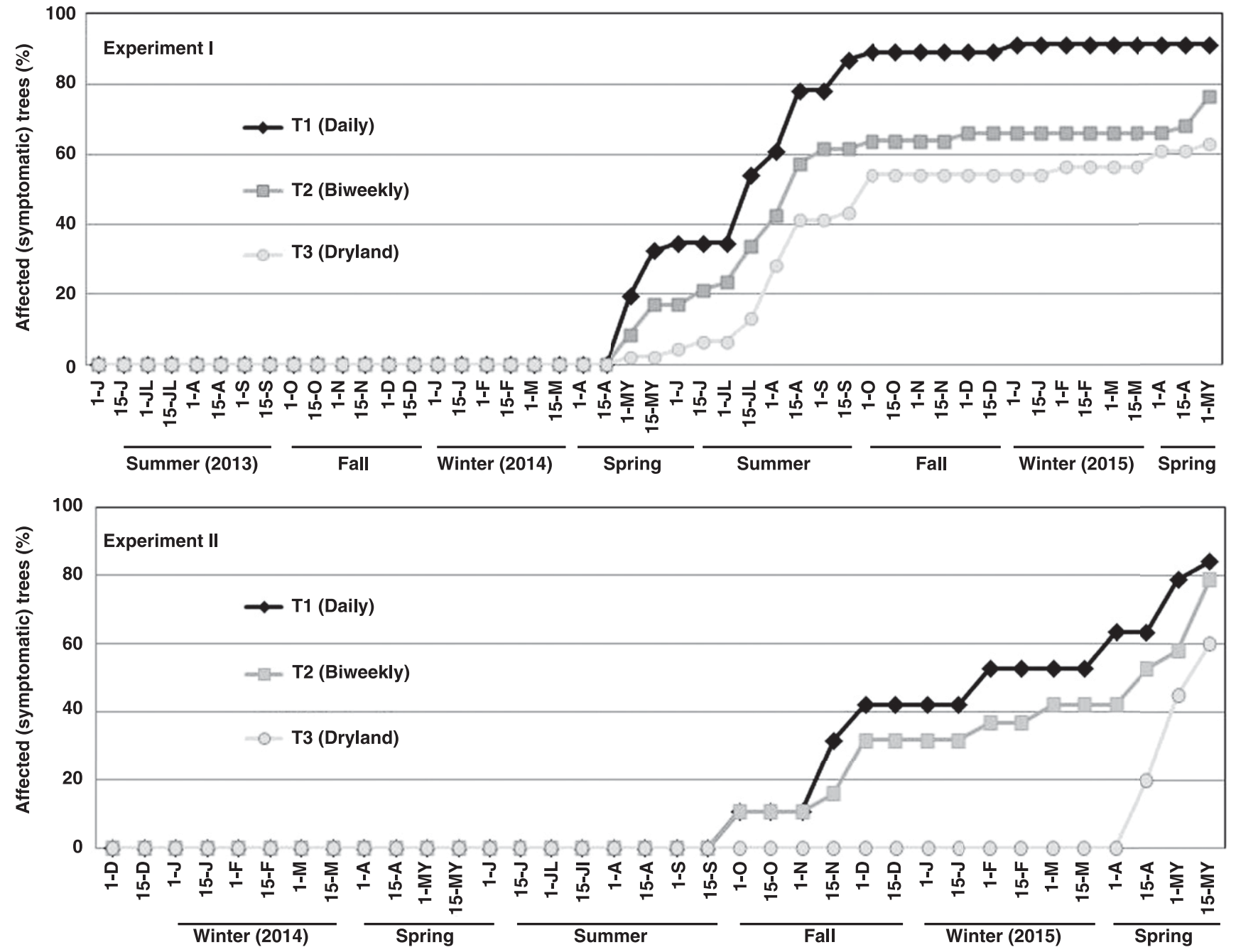

Fig. 1. Verticillium wilt disease incidence over time in Picual olive in two experimental olive orchards (experiments I and II) established on soils naturally infested by Verticillium dahliae and subjected to three irrigation frequencies: daily (T1), biweekly (T2), and dryland (T3). 
differences in RAUDPC values between irrigation and the T3 treatment were observed only in March and April 2015 (Table 2).

The mean disease severity progress curves for the three irrigation treatments in experiment I were well described by a logistic model (pseudo- $R^{2}=0.98$; Fig. 2). In experiment II, the T1 treatment was described by a logistic model with a double sigmoid pattern (pseudo- $R^{2}=0.99$ ), and the disease progression curves for the T2 and T3 treatments could not be fitted to a logistic model (Fig. 2).

Rainfall at experimental plots. The accumulated precipitation at the study fields was $740.2 \mathrm{~mm}$ (from 1 June 2013 to 1 May 2015) and

Table 2. Progression of the disease parameters in two experimental orchards of susceptible Picual olive established on soils naturally infested by Verticillium dahliae and subjected to different irrigation frequencies ${ }^{\mathrm{w}}$

\begin{tabular}{|c|c|c|c|c|c|c|c|c|c|}
\hline \multirow[b]{3}{*}{ Experiments $^{y}$} & \multicolumn{8}{|c|}{ RAUDPC $^{x}$} & \multirow[b]{3}{*}{$\mathrm{DI}_{50}{ }^{\mathrm{z}}$} \\
\hline & \multicolumn{3}{|c|}{2014} & \multirow{2}{*}{$\frac{2015}{1 \text { May }}$} & \multirow{2}{*}{$\frac{2014}{1 \text { December }}$} & \multicolumn{3}{|c|}{2015} & \\
\hline & 1 June & 15 August & 1 October & & & 15 March & 15 April & 15 May & \\
\hline \multicolumn{10}{|l|}{$\overline{\operatorname{Exp} I}$} \\
\hline T1 & $15.8 \mathrm{a}$ & $22.0 \mathrm{a}$ & $24.5 \mathrm{a}$ & $33.7 \mathrm{a}$ & $\ldots$ & $\ldots$ & $\ldots$ & $\ldots$ & 58 \\
\hline $\mathrm{T} 2$ & $7.9 \mathrm{~b}$ & $12.8 \mathrm{a}$ & $15.6 \mathrm{a}$ & $22.9 \mathrm{ab}$ & $\ldots$ & $\ldots$ & $\ldots$ & $\ldots$ & 62 \\
\hline $\mathrm{T} 3$ & $2.1 \mathrm{~b}$ & $4.8 \mathrm{~b}$ & $6.9 \mathrm{~b}$ & $12.8 \mathrm{~b}$ & $\ldots$ & $\ldots$ & $\ldots$ & $\ldots$ & 68 \\
\hline \multicolumn{10}{|l|}{ Exp II } \\
\hline $\mathrm{T} 1$ & $\ldots$ & $\ldots$ & $\ldots$ & $\ldots$ & $4.5 \mathrm{a}$ & $8.9 \mathrm{a}$ & $9.8 \mathrm{a}$ & $12.3 \mathrm{a}$ & 55 \\
\hline $\mathrm{T} 2$ & $\ldots$ & $\ldots$ & $\ldots$ & $\ldots$ & $2.1 \mathrm{a}$ & $4.7 \mathrm{a}$ & $6.2 \mathrm{a}$ & $10.5 \mathrm{a}$ & 66 \\
\hline $\mathrm{T} 3$ & $\ldots$ & $\ldots$ & $\ldots$ & $\ldots$ & $0.0 \mathrm{a}$ & $0.0 \mathrm{~b}$ & $0.2 \mathrm{~b}$ & $3.1 \mathrm{a}$ & 70 \\
\hline
\end{tabular}

${ }^{\text {w }}$ Values in columns followed by the same letter were not significantly different at $P=0.05$ according to Fisher's protected least significant difference test.

${ }^{x}$ Relative area under disease progress curve (RAUDPC) from the beginning of the experiment to the date shown, expressed as a percentage of maximum theoretical curve.

y Experiments (Exp) and treatments: $\mathrm{T} 1=$ daily irrigation, $\mathrm{T} 2=$ Biweekly irrigation, and $\mathrm{T} 3=$ dryland-rainfed.

$\mathrm{z}$ Time in weeks from planting until $50 \%$ of the plants were affected.
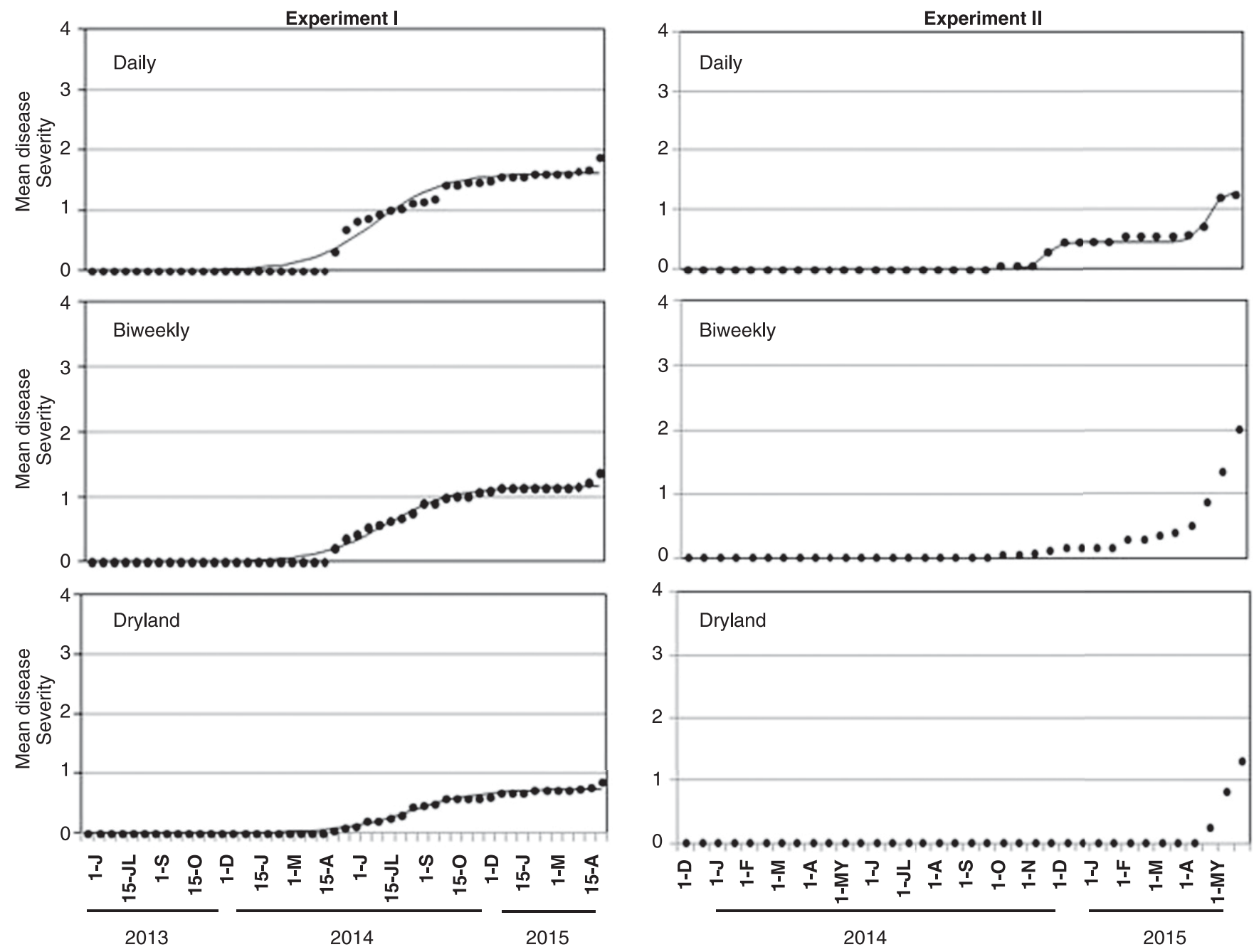

Fig. 2. Mean severity of symptoms of Verticillium wilt over time in Picual olive in the two experimental olive orchards (experiments I and II) established on soils naturally infested with Verticillium dahliae and subjected to three irrigation frequencies: daily (T1), biweekly (T2), and dryland (T3). Disease severity was estimated on a 0-to-4 rating scale that reflected the percentage of plant tissue affected by any of the following symptoms: chlorosis, necrosis, or defoliation, where $0=$ no symptoms; $1=1$ to $33,2=34$ to 66 , and $3=67$ to $99 \%$ affected tissue; and $4=$ dead plant. 
$927.6 \mathrm{~mm}$ (from 1 December 2014 to 15 May 2015) for experiments I and II, respectively. Periods in which higher rainfall was recorded were winter 2013-14 (1 January to $15 \mathrm{March} ; 289.4$ and $309.8 \mathrm{~mm}$ for experiments I and II, respectively) and fall 2014 (1 October to 15 December; 190.8 and $326.0 \mathrm{~mm}$ for experiments I and II, respectively). Weather on 1 June 2013 and in summer 2013 (15 June to 15 September) was particularly dry, and almost no rainfall was registered in experiment I. The driest season in experiment II was fall 2013.

Relationship between the increase in disease parameters (incidence and severity) and soil water content. In experiment $I$, the largest increase in DI occurred in summer 2014 (July through September), in which an average of 20 newly diseased trees was recorded in all treatments (Fig. 3). The greatest symptom severity increments were observed in spring 2014 in trees that received the T1 irrigation treatment (Fig. 3).

The increment of DI observed in spring 2014 (1 April to 1 June) was significantly correlated with the soil water content recorded during this season $(r=0.70, P=0.0033)$ and during the previous fall (1 October to 15 December 2013; $r=0.57, P=0.0252$; Table 3; Fig. 3 ). Disease symptom increments showed high correlation with values of this parameter for the two seasons $(r=0.65, P=0.0079$ and $r=0.8$, $P=0.0003$ for spring 2014 and fall 2013, respectively). Indeed, in fall 2013 (1 October to 15 December), the soil water content in the three irrigation treatments was well differentiated and was 30, 26, and $23 \%$ in the T1, T2, and T3 blocks, respectively (Fig. 3). In spring 2014 (1 April to 1 June), these average soil water content values in $\mathrm{T} 1$ and $\mathrm{T} 2$ were more similar $(\mathrm{T} 1=30.5 \%$ and $\mathrm{T} 2=28.6 \%)$, while the soil water content of the T3 treatment remained near 24\% (Fig. 3). By contrast, the increase in symptom severity in fall 2014 was correlated
( $r=0.54, P=0.037)$ only with the soil water content of spring 2014 (Table 3).

In spring 2015 (1 April to 1 May), five and three new trees developed wilt symptoms in the $\mathrm{T} 2$ irrigation and $\mathrm{T} 3$ treatments, respectively. The average value of the soil water content of the three irrigation treatments was approximately $30 \%$ at this time (Fig. 3). In this experiment (experiment I), the total water consumption after 23 months in the T1 and the $\mathrm{T} 2$ treatments was 68.9 and $54.7 \mathrm{~m}^{3}$, respectively.

In experiment II, disease onset occurred in fall 2014, when eight and six diseased trees were recorded in the $\mathrm{T} 1$ and $\mathrm{T} 2$ treatments blocks, respectively (Fig. 3). The increase in DI and severity recorded during fall 2014 was significantly correlated with the soil water content measured in fall $2014(r=0.67, P=0.0161$ and $r=0.71, P=$ 0.009 , respectively) and the previous spring $(r=0.69, P=0.0116$ and $r=0.64, P=0.025$, respectively; Table 3$)$. However, the increase in DI $\left(R^{2}=0.61, P=0.0142\right)$ and severity $\left(R^{2}=0.59, P=0.0168\right)$ during fall 2014 was better explained by multiple linear regression considering soil moisture in spring and fall 2014.

Soil water content in experiment II between the irrigation treatments in spring and fall 2014 differed similarly to that observed in experiment I (Fig. 3). Soil water content was 23, 27, and $29 \%$ in the T3, T2, and T1 blocks, respectively, just before irrigation in the spring and 23,25 , and $28 \%$, respectively, in the fall.

In spring 2015, an increase in the number of diseased trees $(6,5$, and 12 new trees in T1, T2, and T3, respectively) was again recorded, and disease severity showed the greatest increases (Fig. 3). In this season, the water content of the soil was approximately $30 \%$ in the three treatments. In experiment II, the total water consumption in the T1 and T2 treatments after 18 months was 9.1 and $4.6 \mathrm{~m}^{3}$, respectively (Fig. 3).
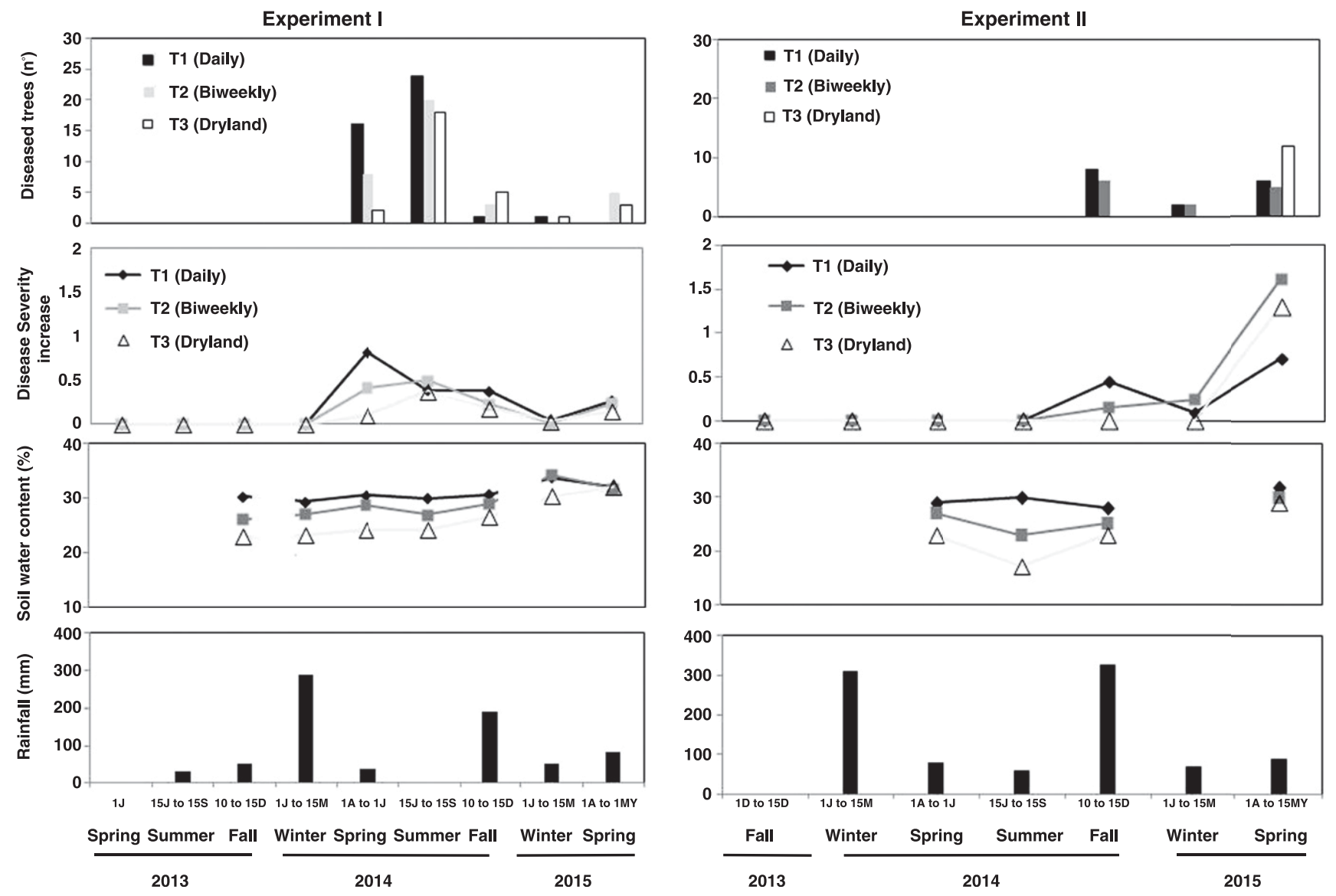

Fig. 3. Number of symptomatic olive trees, disease severity increase, soil water content, and registered rainfall in two experimental orchards of Picual olive (experiments I and II) established on soils naturally infested by Verticillium dahliae and subjected to three irrigation frequencies: daily (T1), biweekly (T2), and dryland (T3). Disease severity was estimated on a 0-to-4 rating scale that reflected the percentage of plant tissue affected by any of the following symptoms: chlorosis, necrosis, or defoliation, where $0=$ no symptoms; $1=1$ to $33,2=34$ to 66 , and $3=67$ to $99 \%$ affected tissue; and $4=$ dead plant. The soil water content was recorded every 15 days just before irrigation, with a time domain reflectometry. Subsequently, in T1 and T2, at every irrigation date (daily or every 15 days, respectively), the soil was irrigated until it reached the upper limit of soil water content. 
these plants did not appear until the next favorable season, spring 2014. For this reason, the value of RAUDPC on 1 June in the T1 treatment was higher than in the rest of treatments (T2 and T3). In spring 2014, favorable conditions to increase disease probably also occurred in the biweekly irrigated plants. Due to that, significant differences were detected in the RAUDPC values in August 2014 among irrigation treatments and the dryland treatment. In this treatment, the conditions were not favorable to disease progression and, consequently, the RAUDPC values across all months were always lower compared with the values of RAUDPC in irrigation treatments.

In experiment II, the epidemic was delayed in plants under T3 treatment. As a consequence, the RAUDPC values were lower, especially in spring 2015, compared with the values of the rest of treatments. This delay, as in experiment I, was probably due to conditions not favorable to disease progression in plants subjected to the T3 treatment.

The interactions between the studied parameters and the experimental variables under natural conditions (e.g., soil and the microbiological characteristics of the soil and environment) of the two study fields are sufficiently complex that further research is needed to explain their effect on VWO development. The final values of DI were similar in both experiments and did not differ between irrigation treatments. Thus, these data suggest that the sum of the long-term effect of noncontrolled parameters that influence disease development such as temperature, ID, the virulence of isolates, and other harmful agronomic practices was similar in the two experimental trials.

Based on our previous work on VWO in microplots, we suggest that disease development was directly influenced not by the frequency of irrigation schedule but by the water content in the soil profile. Thus, we hypothesize that VWO could be managed by adjusting water content in soil to lower values that do not affect the physiology (particularly the growth) of the plants but do reduce the incidence or severity of symptoms. Indeed, we determined, in our research during favorable periods for disease development, that there were soil water contents that did not favor disease development and where increments of DI and severity were zero (Table 3 ).

In the present study, we included $\mathrm{T} 1$ and $\mathrm{T} 2$ irrigation treatments because we wanted to compare two irrigation frequencies for which the soil water content was calculated to try to produce maximum plant growth. Moreover, the T3 treatment, in which the tree growth could be more affected depending on the rainfall, would be a good control regarding the influence on disease of keeping water low in the soil profile. The weekly irrigation treatment was not studied, as was done by Pérez-Rodríguez et al. (2015), because we thought that, under field conditions, its effect on disease development would be very difficult to differentiate from the effect of the T1 irrigation. Furthermore, its omission allowed us to simplify the irrigation program.

We also investigated correlations between the soil water content recorded in the soil profile and DI and severity. In the two fields, and during the observation period, a significant correlation between the DI and severity increments during spring and fall with the soil water content of the same or previous favorable seasons was observed (Table 3; Fig. 3). All these relationships were well adjusted to an asymptotic model, in which the asymptote trended toward a moisture content of $30 \%$. The value was close to the water content in the upper limits of experiment I (37\%) and experiment II (32\%). Additionally, in experiment II, it was observed that, if the soil water content values in the spring and fall of 2014 were studied jointly, a higher correlation was obtained with the increasing incidence and severity of symptoms in the fall of 2014. These results demonstrate that the soil water content in our favorable seasons (spring and fall) influences VWO development.

It is possible that the reduction of the available water in soil that reduced the impact of VWO probably influenced plant vegetative development. In our experiments, we did not measure tree growth. Threshold values of soil water content that would not reduce growth of young olive trees similar to the trees used in the present study and planted in a clay soil would be approximately $26 \%$ (Steduto et al. 2012; Villalobos et al. 2002). In our work, threshold water contents of 25 and $27 \%$ were measured in experiments I and II, respectively. DI and severity were zero when soil moisture content was to 24.3 and $23.6 \%$ in experiments I and II, respectively. Therefore, we suspect that tree growth and yield were also subsequently reduced.

Total recorded rainfall in this treatment was 740.2 and $927.6 \mathrm{~mm}$ in experiment I and II, respectively. Winter 2013-14 (1 January to 15 March; 289.4 and $309.8 \mathrm{~mm}$ for experiments I and II, respectively) and fall 2014 (1 October to 15 December; $326.0 \mathrm{~mm}$ for experiment II) were particularly wet (Fig. 3). However, winter 2014-15 was considerably drier than the previous year in both fields (53 and $67.8 \mathrm{~mm}$ in experiments I and II, respectively), although the soil moisture content at the beginning of spring (April) 2015 was close to the highest recorded water content in $\mathrm{T} 3$ treatments, particularly in experiment II (Fig. 3). Thus, in this treatment, there were long periods without rainfall that may have had a negative influence on tree growth and, consequently, reduced crop yield. This reduction in yield needs to be considered by farmers in cases of disease risk, although it is a fairly common practice for farmers to stop irrigation when the disease has increased alarmingly to prevent high mortality (López-Escudero et al. 2010). This was observed in experiment I, in which the percentage of dead plants at the end of the observations was significantly higher in the T1 irrigation treatment $(28.4 \%)$ than in the T3 treatment $(6.4 \%)$.

The data from this study suggest that, under the climatic conditions of the Guadalquivir Valley, careful scheduling of irrigation during periods of low rainfall in the spring or fall may be considered to manage VWO management because keeping the soil water content below $24 \%$ may delay or slow disease development. For example, farmers could consider a biweekly irrigation frequency rather than daily irrigation, or even not irrigating the affected orchard for a period of time. However, the effect of reduced irrigation scheduling on yield needs to be determined.

\section{Acknowledgments}

This research was partially funded by Project AGL2007-65766 (Spanish Ministerio de Ciencia e Innovación, co-financed by FEDER of the EU) and by a contract between the University of Córdoba and The Spanish Interprofessional Olive Oil Association (UG 400544). We thank the Oficina Comarcal Agraria "Sierra Morena/Campiña Jaén" (Andújar, Jaén), the Comunidad de Regantes "Ntra. Sra. de los Dolores" (Arjona, Jaén), and R. Jiménez del Río for technical assistance at the plot of experiment I; the Oficina Comarcal Agraria "Las Marismas" (Lebrija, Sevilla) and the Sociedad Cooperativa Andaluza "Agroquivir" (Trajano, Sevilla) for permitting us to collect from their property the infested soil necessary for experiment II; F. Gonzalez for his constant valuable support at both experimental plots; and J. M. Moral, who holds a Talent Hub fellowship launched by the Andalusian Knowledge Agency and cofounded by the European Union's 7th FP.

\section{Literature Cited}

Anonymous. 2015. Redes de estaciones agroclimáticas de Andalucía. Online publication. http://www.juntadeandalucia.es/agriculturaypesca/ifapa/ria/servlet/ FrontController

Berlanger, I. and Powelson, M. L. 2000. Verticillium wilt. Online publication Plant Health Instruct. doi:10.1094/PHI-I-2000-0801-01

Bletsos, F. A., Thanassoulopoulos, C. C., and Roupakias, D. G. 1999. Water stress and Verticillium wilt severity on eggplant (Solanum melongena L.). J. Phytopathol. 147:243-248.

Butterfield, E. J., and DeVay, J. E. 1977. Reassessment of soil assays for Verticillium dahliae. Phytopathology 67:1073-1078.

Caballero, J. M., and Del Río, C. 2008. The olive world germplasm bank of Spain. Acta Hortic. 791:31-38.

Caballero, J. M., and Del Río, C. 2010. Propagation methods. Pages 83-112 in: Olive Growing. D. Barranco, R. Fernández-Escobar, and L. Rallo, eds. Junta de Andalucía/Mundi Prensa/RIRDC/AOA, Pendle Hill, NSW, Australia.

Campbell, C. L., and Madden, L. V. 1990. Introduction to Plant Disease Epidemiology. John Wiley and Sons, New York.

Cappaert, M. R., Powelson, M. L., Christensen, N. W., and Crowe, F. J. 1992 Influence of irrigation on severity of potato early dying and tuber yield. Phytopathology 82:1448-1453.

Emechebe, A. M. 1980. The effect of soil moisture and of N, P and K on incidence of infection of cacao seedlings inoculated with Verticillium dahliae. Plant Soil 54:143-147.

Fernández, J. E., Moreno, F., Cabrera, F., Arrue, J. L., and Martín-Aranda, J. 1991. Drip irrigation, soil characteristics and the root distribution and root activity of olive trees. Plant Soil 133:239-251.

Green, R. J., Jr. 1980. Soil factors affecting survival of microsclerotia of Verticillium dahliae. Phytopathology 70:353-355.

Hiemstra, J. 2015. Guide for best practices in managing Verticillium wilt in olive. Project VERTIGEEN. Contract No. FP7-SME-2011-2-286140. Online publication. 
http://www.vertigeen.eu/files_media/1429516669_vertigeen_deliverable_6_13 guide_of_best_practices_final.pdf

Hiemstra, J., and Harris, D. 1998. Compendium of Verticillium wilt in tree species. Ponsen \& Looijen, Wageningen, The Netherlands.

Huisman, O. C. 1982. Interrelationship of root growth dynamics to epidemiology of root invading fungi. Annu. Rev. Phytopathol. 20:303-327.

Huisman, O. C., and Ashworth, L. J. 1974. Quantitative assessment of V. albo-atrum in field soils: Procedural and substrate improvements. Phytopathology 64:1043-1044.

Jiménez-Díaz, R. M., Cirulli, M., Bubici, G., Jiménez-Gasco, M. M., Antoniou, P. P., and Eleftherios, C. T. 2012. Verticillium wilt, a major threat to olive production: Current status and future prospects for its management. Plant Dis. 96:304-329.

Kaplan, E. L., and Meier, P. 1958. Nonparametric-estimation from incomplete observations. J. Am. Stat. Assoc. 53:457-481.

Karaca, I., Karcihoglu, A., and Ceylân, S. 1971. Wilt disease of cotton in the Ege region of Turkey. Page 119 in: Verticillium Wilts. G. F. Pegg and B. L. Brady, eds. CABI Publishing, Trowbridge, UK.

(Lahkim) Tsror, L. 2011. Review: Epidemiology and control of Verticillium wilt on olive. Isr. J. Plant Sci. 59:59-69.

López-Escudero, F. J., and Blanco-López, M. A. 2001. Effect of a single or double soil solarization to control Verticillium wilt in established olive orchards in Spain. Plant Dis. 85:489-496.

López-Escudero, F. J., and Blanco-López, M. A. 2005a. Effects of drip irrigation on population of Verticillium dahliae in olive orchards. J. Phytopathol. 153: 238-239.

López-Escudero, F. J., and Blanco-López, M. A. 2005b. Isolation and morphologic characterization of microsclerotia of Verticillium dahliae isolate from soil. Biotechnology 4:296-304.

López-Escudero, F. J., Del Río, C., Caballero, J. M., and Blanco-López, M. A. 2004. Evaluation of olive cultivars for resistance to Verticillium dahliae. Eur. J. Plant Pathol. 110:79-85.

López-Escudero, F. J., and Mercado-Blanco, J. 2011. Verticillium wilt of olive: A case study to implement an integrated strategy to control a soil-borne pathogen. Plant Soil 344:1-50.
López-Escudero, F. J., Mercado-Blanco, J., Roca, J. M., Valverde-Corredor, A. and Blanco-López, M. A. 2010. Verticillium wilt of olive in the Guadalquivir Valley (southern Spain): Relations with some agronomical factors and spread of Verticillium dahliae. Phytopathol. Mediterr. 49:370-380.

Mercado-Blanco, J., Rodríguez-Jurado, D., Parrilla-Araujo, S., and Jiménez-Díaz, R. M. 2003. Simultaneous detection of the defoliating and nondefoliating Verticillium dahliae pathotypes in infected olive plants by duplex, nested polymerase chain reaction. Plant Dis. 87:1487-1494.

Pérez-Rodríguez, M., Alcántara, E., Amaro, M., Serrano, N., Lorite, I. J., Arquero, O., Orgaz, F., and López-Escudero, F. J. 2015. The influence of irrigation frequency on the onset and development of Verticillium wilt of olive. Plant Dis. 99:488-495.

Saadatmand, A. R., Banishashemi, Z., Sepaskhah, A. R., and Maftour, M. 2006 Effect of water potential on germination of Verticillium dahliae microsclerotia. Phytopathol. Mediterr. 45:225-230.

Shufelt, C., and Linderman, R. G. 1986. The influence of irrigation on the incidence and severity of Verticillium wilt of Norway maple. Page 50 in: (Abstr.) 4th Int. Verticillium Symp. Guelph, ON, Canada.

Steduto, P., Hisiao, T. C., Fereres, E., and Raes, D. 2012. Crop Yield Response to Water. Food and Agriculture Organization of the United Nations, Rome.

Trapero, C., Serrano, N., Arquero, O., Del Río, C., Trapero, A., and LópezEscudero, F. J. 2013. Field resistance to Verticillium wilt in selected olive cultivars grown in two naturally infested soils. Plant Dis. 97:668-674.

Vigouroux, A. 1984. Verticilliose et bactériose deux importants facteurs de dépérissment de l'abricotier. Arboric. Fruit. 31:31-35.

Villalobos, F. J., Orgaz, F., Mateos, L., and Fereres, E. 2002. Fitotecnia bases y tecnologías de la producción agrícola. Mundi-prensa, Madrid.

Wheeler, T. A., Bordovsky, J. P., Keeling, J. W., Mullinix, B. G., Jr., and Woodward, J. E. 2012. Effects of crop rotation, cultivar, and irrigation and nitrogen rate on Verticillium wilt in cotton. Plant Dis. 96:985-989.

Xiao, C. L., and Subbarao, K. V. 2000. Effects of irrigation and Verticillium dahliae on cauliflower root and shoot growth dynamics. Phytopathology 90 995-1004. 